\title{
BEBERAPA JENIS KELOMPOK GABUS (MARGA CHANNA) DI DAERAH ALIRAN SUNGAI MUSI, SUMATERA SELATAN")
}

\author{
Azwar Said) \\ Peneliti pada Balai Riset Perikanan Perairan Umum, Mariana-Palembang \\ Teregristrasi I tanggal: 2 Juni 2006; Disetujui terbit tanggal: 19 Juni 2006
}

\begin{abstract}
ABSTRAK
Sungai Musi merupakan sungai terpanjang dan terbesar di Sumatera, yang dimanfaatkan untuk berbagai aktivitas seperti transportasi, baku air minum, dan perikanan terutama tangkap. Di Sungai Musi diperkirakan telah terjadi penurunan keragaman marga channa, semula terdapat 6 jenis, tetapi saat ini hanya ditemukan 5 jenis yaitu serandang (Channa pleurophthalmus), bujuk (Channa cyanospilos), toman (Channa micropeltes), sarko (Channa lucius), dan gabus (Channa striata) sedangkan jalai (Channa marulioides) sudah jarang tertangkap terutama pada lokasi penelitian. Hal ini, kemungkinan karena over fishing dan atau perubahan atau hilang habitat.
\end{abstract}

KATA KUNCI: kelompok gabus, daerah aliran Sungai Musi, Sumatera Selatan

\section{PENDAHULUAN}

Sungai Musi merupakan sungai terpanjang dan terbesar di Sumatera dengan panjang $\pm 510 \mathrm{~km}$. Bagian hilir dipengaruhi oleh pasang surut air laut sepanjang $\pm 146 \mathrm{~km}$ dimulai dari muara sungai di Desa Sungsang dekat Selat Bangka sampai dengan Desa Tebing Abang Kabupaten Banyuasin (Samuel et al., 2002). Di bagian tengah daerah aliran Sungai Musi (middle stream) merupakan rawa banjiran sebagai habitat berbagai jenis ikan termasuk ikan marga channa (Utomo et al., 1995).

Daerah aliran Sungai Musi di Sumatera Selatan merupakan ekosistem yang berperan penting sebagai sentra produksi ikan, sumber mata pencaharian penduduk, dan penyedia protein ikan bagi masyarakat. Daerah ini telah lama dimanfaatkan oleh masyarakat untuk perikanan tangkap dan beberapa bagian telah menunjukkan penurunan hasil tangkapan. Penurunan ini disebabkan oleh penangkapan yang intensif dan juga perubahan atau hilang habitat ikan tersebut akibat perubahan fungsi lahan. Bahkan daerah aliran Sungai Musi sudah termasuk kritis, karena penggundulan akibat penebangan liar (Anonim, 2006).

Marga channa merupakan suku ikan air tawar yang hidup di kawasan tropis Afrika, Asia Selatan, Asia Tenggara, dan Asia Timur. Ikan ini sering disebut sebagai ikan kepala ular (snakehead), karena bentuk kepala lebar dan bersisik besar, mulut bersudut tajam, sirip punggung dan sirip dubur panjang, dan tinggi hampir sama. Semua jenis mampu menghirup oksigen dari atmosfer, karena pada bagian insang terdapat alat pernapasan tambahan. Beberapa jenis antara lain merupakan ikan ekonomis penting baik sebagai ikan hias maupun ikan konsumsi (Kotellat et al., 1993)

\section{Marga Channa di Daerah Aliran Sungai Musi}

Salah satu jenis ikan ekonomis penting yang banyak terdapat di daerah aliran Sungai Musi adalah marga channa. Beberapa marga channa yang terdapat di daerah aliran Sungai Musi adalah serandang (Channa pleurophthalmus), sarko (Channa lucius), bujuk (Channa cyanospilos), toman (Channa micropeltes), gabus (Channa striata), dan jalai (Channa marulioides) namun sudah jarang ditemukan. Populasi ikan tersebut di atas cenderung mengalami penurunan yang kemungkinan disebabkan oleh penangkapan yang berlebihan guna memenuhi permintaan industri rumah tangga, karena ikan ini terutama jenis gabus (Channa striata) digunakan untuk membuat makanan khas Sumatera Selatan yaitu empek-empek dan kerupuk. Ikan ini juga dimanfaatkan untuk pembuatan ikan asin yang di pasaran mempunyai nilai jual tinggi.

Jalai (Channa marulioides) merupakan ikan asli (native spesies) Sungai Musi, yang tersebar di daerah lain di Indonesia yaitu di Indragiri, Batang Hari, Bangka Belitung, Samarinda, dan Kapuas. Dikenal dengan nama emperor snakehead, darkfin snakehead, jaloy atau jalai, toman bunga yang mirip dengan ikan kutuk (Channa melanoptera) (Anonim, 2006a), yang membedakan keduanya adalah warna. Ciri ikan jalai mempunyai warna hitam, berpinggiran putih pada pangkal ekor bagian atas, tidak mempunyai gigi taring pada vomer atau palatum, 3,5 sisik antara guratan sisi dan pada bagian depan pangkal jari-jari sirip punggung, dan panjang dapat mencapai $65 \mathrm{~cm}$. Ikan ini mempunyai nilai ekonomis seperti di Singapura harga S\$100 per individu (Anonim, 2006b). Berdasarkan pada penelitian ikan jalai sudah sangat sulit ditemukan di daerah aliran Sungai Musi hal ini 
kemungkinan karena populasi yang sudah menurun (Said et al., 2004).

Toman (Channa micropeltes) atau yang lebih dikenal dengan giant snakehead, red snakehead, redline snakehead, malabar snakehead, mala, ikan toman, toman (Malaysia), pla chado (Thailand), pla melang pu (Bangkok, Thailand), trey diep (juvenile) dan trey chhdaur (adult; Cambodja), toman, anak toman, dan gabus tobang (Kalimantan). Nama lain ikan jenis ini adalah Ophiocephalus serpentinus Cuvier, Ophicephalus bivittatus Bleeker, Ophiocephalus stevensii Bleeker, Ophiocephalus diplogramma Day, Ophiocephalus diplogramme, dan Ophiocephalus studeri Volz. Channa micropeltes merupakan jenis yang paling besar di antara jenis marga channa dan mempunyai kemampuan adaptasi yang tinggi di perairan air tawar. Di Indonesia tersebar di Sumatera bagian Tenggara, Kalimantan Barat, Jawa, dan Bangka Belitung, dapat mencapai ukuran 1 sampai dengan 1,5 m dengan bobot lebih dari 20 kg. Penangkapan pada umumnya menggunakan pancing dengan ukuran mata pancing 5 sampai dengan 8. Ikan toman cukup banyak ditemukan di sepanjang daerah aliran Sungai Musi. Pada Channa micropeltes terdapat garis warna orange dari moncong ke sirip ekor bagian atas dan bawah dibatasi oleh garis berwarna hitam yang kemudian terputus menjadi bintik-bintik yang tidak beraturan atau bercak. Vomer dan palatine mempunyai sederetan gigi kecil berbentuk taring (Kotellat et al., 1993).

Bujuk (Channa cyanospilos) merupakan ikan asli Sungai Musi. Penyebaran dimulai dari Sumatera, Kalimantan, Jambi, Riau, dan juga Semenanjung Malaysia. Ciri ikan ini adalah mempunyai bintik-bintik biru pucat tersebar pada bagian bawah badan yaitu bermula dari tutup insang sampai dengan batang ekor dan gigi taring terdapat pada bagian rahang bawah. Beberapa penulis mengatakan bujuk sebagai bluespotted snakehead (kepala ular berbintik biru) karena warna biru yang terdapat pada tubuh merupakan ciri khas yang tidak dimiliki oleh marga channa lain yang berasal dari Indonesia (Sumatera) dan Malaysia. Ikan bersifat karnivora dan mempunyai kebiasaan membuat sarang untuk menempelkan telur (Anonim, 2006c; Kotellat et al., 1993).

Gabus (Channa striata) banyak terdapat di perairan tawar dan merupakan ikan konsumsi yang pada umumnya dikeringkan atau diasinkan. Ikan gabus mempunyai harga ekonomi yang tinggi. Ikan ini dapat bertahan hidup pada musim kering dengan cara bersembunyi di lumpur dasar perairan. Penyebaran sangat luas antara lain di Indonesia (Sulawesi, Paparan Sunda, Sunda Kecil, dan Maluku), Sri lanka, Philipina, Indocina, dan Cina, dapat mencapai panjang sampai dengan $90 \mathrm{~cm}$ dan bersifat karnivora. Nama lain juga dikenal dengan Ophicephalus striatus Bloch, Ophiocephalus vagus Peters, Ophiocephalus striatus var. qualamudensis Gianferrari, merupakan jenis marga channa yang paling dominan tertangkap di daerah aliran Sungai Musi. Pada sisi badan mempunyai pita warna berbentuk < mengarah ke depan, tidak tedapat gigi taring pada vomer dan palatine, terdapat sisik berjumlah 4 sampai dengan 5 antara gurat sisi dan pangkal jari-jari sirip punggung bagian depan (Kotellat et al., 1993)

Serandang (Channa pleurophthalmus) merupakan ikan yang bersifat predator. Seperti marga channa lain, ikan ini merupakan ikan konsumsi penting dengan harga yang sedang. Mempunyai ciri bercak bulat hitam pada bagian sisi badan dengan bulatan kuning berjumlah 4 sampai dengan 5 buah, gigi kecil dan gigi taring berjumlah 4 sampai dengan 5 buah pada palatine, sisik antara gurat sisi dan bagian depan pangkal jari-jari sirip punggung. Wilayah penyebaran meliputi Kalimantan (Sungai Kapuas dan Barito) dan Sumatera (Anonim, 2006d; Kotellat et al., 1993).

Berdasarkan pada perbandingan morfometri ukuran kepala dan panjang total, dari ke- 5 jenis marga channa yang ada di daerah aliran Sungai Musi, yang mempunyai nilai terbaik adalah ikan toman (Channa micropeltes) dengan nilai perbandingan 1:3,8, dengan anggapan bahwa bagian yang dikonsumsi atau keperluan lain adalah bagian badan. (Said et al., 2004). Di bawah ini disajikan berbagai jenis gambar Channa sp di daerah aliran Sungai Musi (Gambar 1.)

\section{Habitat Marga Channa di Daerah Aliran Sungai Musi}

Jenis marga channa merupakan jenis ikan tropis dan jika akan diintroduksi ke perairan lain harus terletak di daerah yang mempunyai iklim tropis (iklim yang sama). Mampu beradaptasi di berbagai perairan air tawar baik kolam, danau, sungai, rawa, dan waduk. Mempunyai kebiasaan hidup di vegetasi rawa atau sungai berarus lambat.

Marga channa merupakan ikan yang mampu hidup di perairan dengan karakteristik $\mathrm{pH}$ asam, oksigen terlarut relatif rendah, dan $\mathrm{CO}_{2}$ tinggi (Tabel 1). Berdasarkan pada warna air, ikan marga channa mampu beradaptasi di lingkungan yang mempunyai kandungan humus yang tinggi yang berasal dari gambut. Daerah tersebut merupakan hutan rawa yang padat dengan tumbuhan air yang didominasi oleh graminae dengan sedikit tumbuhan tingkat tinggi. Beberapa lokasi penelitian di Gumai, Kabupaten Muara Enim merupakan lokasi yang mempunyai keragaman jenis marga channa tinggi. Di daerah tersebut ditemukan 5 jenis. Ciri yang membedakan 


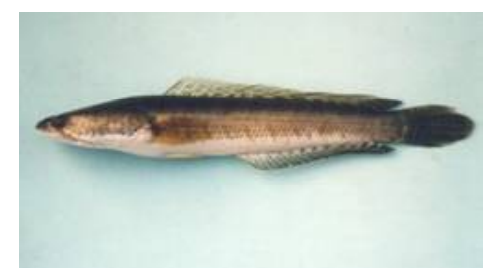

Gabus (Channa striata)

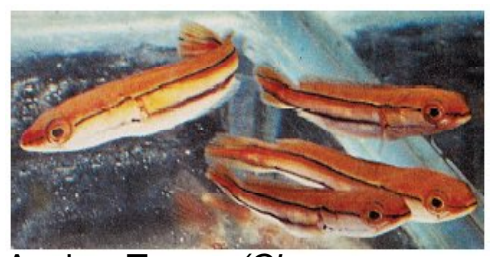

Anakan Toman (Channa

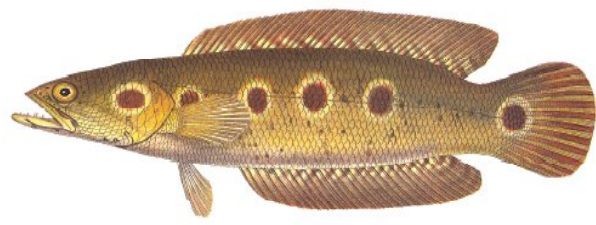

Serandang (Channa pleurophthalmus)

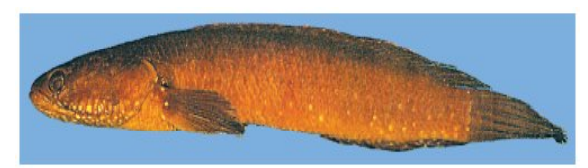

Jalai (Channa marulioides)
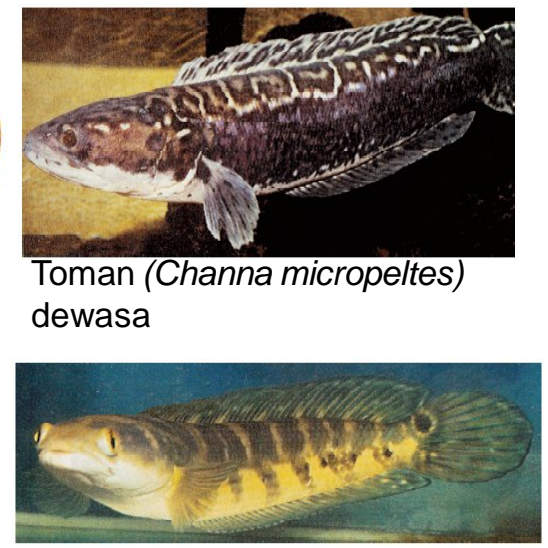

Bujuk (Channa cyanospilos) micropeltes)

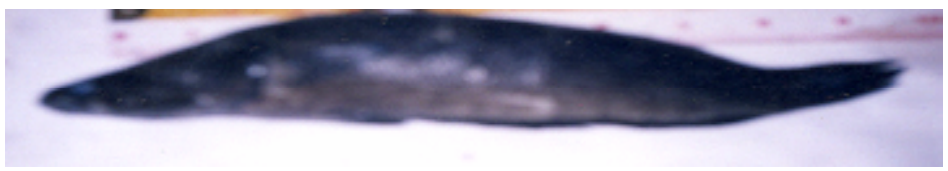

Sarko (Channa lucius)

Gambar 1. Jenis marga channa di daerah aliran Sungai Musi.

Tabel 1. Karakteristik kualitas air habitat marga channa di daerah aliran Sungai Musi

\begin{tabular}{lcc}
\hline \multirow{2}{*}{ Parameter } & \multicolumn{2}{c}{ Lokasi } \\
\cline { 2 - 3 } & Muara Enim & Musi Banyuasin \\
\hline Suhu $\left({ }^{\circ} \mathrm{C}\right)$ & $28-30$ & $27-30$ \\
$\mathrm{pH}($ Unit) & $5,5-6,5$ & $5,5-6$ \\
Oksigen terlarut $(\mathrm{ppm})$ & $4-5,5$ & $3,7-5$ \\
$\mathrm{CO}_{2}(\mathrm{ppm})$ & $5-7,6$ & $5,5-7$ \\
Warna air & Kuning, kecoklatan, dan hitam & Kuning dan kecoklatan \\
\hline
\end{tabular}

lokasi tersebut dengan lainnya adalah air yang berwarna hitam yang merupakan lahan gambut, sehingga daerah ini kemungkinan dapat di jadikan suaka atau reservat. Di bawah ini disajikan beberapa habitat marga channa di daerah aliran Sungai Musi (Gambar 2) (Said et al., 2004).

\section{Produksi Marga Chana di Daerah Aliran Sungai Musi}

Marga channa termasuk jenis ikan karnivora yang mempunyai daya adaptasi tinggi terhadap lingkungan. Terdapat perbedaan hasil tangkapan ikan ketika musim penghujan dan musim kemarau, di mana produksi pada musim kemarau lebih tinggi. Produksi ikan di Kabupaten Muara Enim dan Kabupaten Musi Banyuasin disajikan pada Tabel 2 pada lokasi penelitian.Marga channa jenis jalai, sarko, dan serandang merupakan jenis yang jarang tertangkap
(Tabel 2). Marga channa di daerah aliran Sungai Musi ada 6 jenis, 5 jenis antara lain serandang (Channa pleurophthalmus), sarko (Channa lucius), bujuk (Channa cyanospilos), toman (Channa micropeltes), dan gabus (Channa striata) (Said et al., 2004) dan 1 jenis lain jalai (Channa marulioides) tidak tertangkap namun diperkirakan ada. Berdasarkan pada informasi dari masyarakat nelayan. Hal tersebut, menunjukkan bahwa keragaman marga channa mulai menurun. Demikian juga, hasil tangkapan mengalami penurunan dibandingkan produksi 1 sampai dengan 3 tahun sebelum (hasil wawancara langsung dengan nelayan). Beberapa penyebab menurun populasi ikan antara lain:

1. Kerusakan habitat alami, seperti makin menurun populasi tanaman tingkat tinggi yang merupakan tempat berlindung. Daerah aliran Sungai Musi sudah termasuk kritis karena gundul dan banyak ditumbuhi semak belukar akibat penebangan liar. 


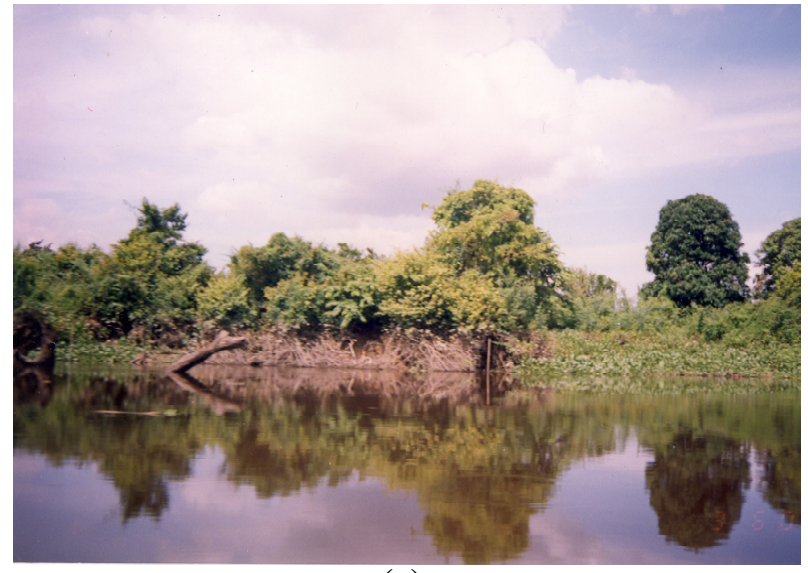

(a)

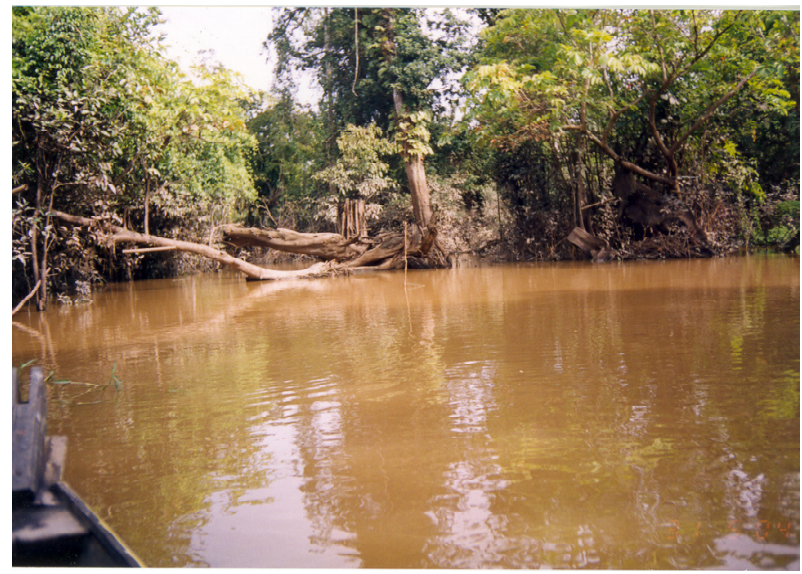

(b)

Gambar 2. Habitat marga channa di Kabupaten Muara Enim dan habitat marga channa di Kabupaten Musi Banyuasin.

Lahan seluas 370.000 ha merupakan daerah hutan lindung, 1,3 juta ha adalah kawasan lindung di luar hutan dan 1,3 juta ha adalah kawasan pertanian (Anonim, 2006d). Lahan kritis tersebut terletak di Kabupaten Banyuasin, Musi Rawas, Ogan lilir, dan Musi Banyuasin yang merupakan lokasi ditemukan berbagai jenis marga channa. Kondisi daerah aliran Sungai Musi di bagian hulu dan sungai lain yang bermuara ke Sungai Musi memprihatinkan, antara lain di kawasan Sempadan Sungai Lematang di Pagar Alam, Sungai Musi di Ulu Musi, Padangtepung, Lahat, Sungai Beliti di Lubuk Linggau, dan Sungai Musi di Muara Enim yang merupakan habitat marga channa. Kawasan di pinggiran sungai pada umumnya hanya ditumbuhi semak belukar kecil atau sudah gundul sama sekali. Pohon-pohon besar ditebang, diganti tanaman palawija atau tanaman kebun. Selain itu, akibat dari penebangan pohon kerusakan ini juga diakibatkan oleh aktivitas penggalian pasir dan penggalian batu (Anonim, 2006d).

2. Over fishing yaitu penangkapan berlebih, cara penangkapan yang disebut ngesar menghasilkan berton-ton ikan baik besar maupun kecil. Hasil penelitian tahun 2004, menunjukkan hasil tangkapan nelayan di Kabupaten Muara Enim sebagai berikut gabus 8.080 ton, toman 6.075 ton, bujuk 1.527 ton, serandang 1.102 ton, dan sarko 0,017 ton. Di Kabupaten Musi Banyuasin gabus 10.366 ton, toman 6.222 ton, dan bujuk 1.452 ton. Over fishing ini kemungkinan karena harga jual ikan jenis ini cukup tinggi di pasaran yaitu berkisar Rp.15.000 sampai dengan 22.000 per kg.

3. Belum banyak daerah yang ditetapkan sebagai daerah reservat (suaka) dan sebagian besar merupakan daerah penangkapan.

4. Penggunaan alat tangkap yang tidak ramah lingkungan seperti setrum (electric fishing), alat

Tabel2. Produksi marga channa di Kabupaten Muara Enim dan Kabupaten Musi Banyuasin tahun 2004

\begin{tabular}{llcccc}
\hline \multirow{2}{*}{ Jenis ikan } & Nama ilmiah & \multicolumn{2}{c}{ Kabupaten Muara Enim } & \multicolumn{2}{c}{ Kabupaten Musi Banyuasin } \\
\cline { 3 - 6 } & $\begin{array}{c}\text { Musim } \\
\text { penghujan } \\
(\mathrm{kg})\end{array}$ & $\begin{array}{c}\text { Musim } \\
\text { kemarau } \\
(\mathrm{kg})\end{array}$ & $\begin{array}{c}\text { Musim } \\
\text { penghujan } \\
(\mathrm{kg})\end{array}$ & $\begin{array}{c}\text { Musim } \\
\text { kemarau } \\
(\mathrm{kg})\end{array}$ \\
\hline Gabus & Channa striata & 520 & 7.560 & 1.130 & 9.236 \\
Toman & C. micropeltes & 215 & 5.860 & 376 & 58.346 \\
Bujuk & C. cyanospilos & 110 & 1.427 & 329 & 1.123 \\
Serandang & C. pleurophthalmus & 124 & 978 & - & - \\
Sarko & Channa lucius & 6 & 11 & - & - \\
Jalai & C. marulioides & - & - & - & - \\
\hline
\end{tabular}


ini pada umumnya digunakan sepanjang Sungai Musi, dilengkapi dengan tangguk berdiameter 2 $\mathrm{m}$ yang dialiri listrik dari 2 aki.

5. Pencemaran bahan kimia yang menyebabkan kematian ikan (Sriwijaya Post, 2003).

Komposisi hasil tangkapan marga channa di Kabupaten Muara Enim dan Kabupaten Musi Banyuasin disajikan pada Gambar 4 dan 5.

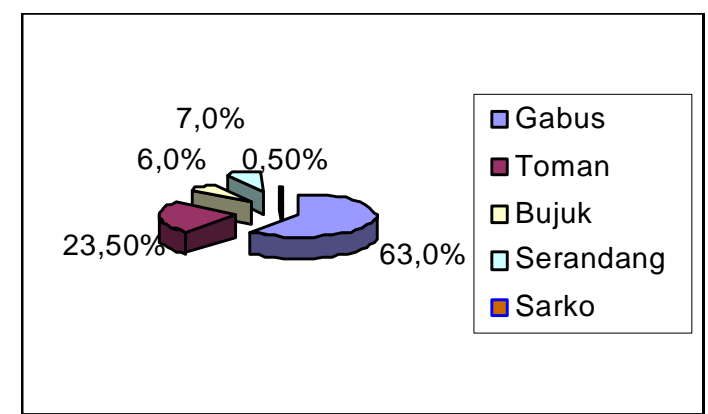

Gambar 4. Komposisi hasil tangkapan marga channa di Kabupaten Muara Enim.

ini, kemungkinan karena ikan gabus mempunyai daya adaptasi yang baik sehingga dapat mempertahankan populasi dalam jumlah yang banyak.

Alat tangkap yang digunakan nelayan ketika musim hujan adalah tajur (hook line), jaring (gill net), dan tangkul (life net). Sedangkan pada musim kemarau adalah empang (barrier traps), sengkirai bilah (pot traps), dan penangkapan dengan cara ngesek lebung (active barrier). Jenis alat yang digunakan bersifat pasif dan aktif. Alat tangkap yang banyak digunakan oleh nelayan setempat adalah tajur, karena tidak membutuhkan biaya yang besar dalam pembuatan dan tidak membutuhkan waktu lama dalam pemasangan dan pada umumnya tangkapan yang dihasilkan juga lebih banyak. Tangkul yang digunakan pada umumnya berukuran $3 \times 4 \mathrm{~m}$, digunakan pada daerah aliran air yang tidak terlalu deras dan tidak terdapat banyak tumbuhan air. Empang merupakan usaha penangkapan dengan alat tangkap berupa anyaman pagar bambu (sayap) untuk menghadang ruaya ikan agar masuk ke dalam kantong (lulung) perangkap. Dari segi hasil tangkapan, alat tangkap ini merupakan alat tangkap yang paling efektif karena jumlah hasil tangkapan yang didapatkan banyak dan hampir meliputi semua jenis ikan yang ada, tetapi tidak selektif karena hampir semua ukuran ikan dapat tertangkap. Sengkirai bilah merupakan alat tangkap yang terbuat dari bambu yang dianyam menyerupai kubus. Dalam pengoperasian alat ini memerlukan bambu kecil
Di Kabupaten Muara Enim dtemukan 5 jenis marga channa yaitu serandang (Channa pleurophthalmus), bujuk (Channa cyanospilos), toman (Channa micropeltes), sarko (Channa lucius), dan gabus (Channa striata). Di Kabupaten Musi Banyuasin hanya ditemukan 3 jenis yaitu gabus (Channa striata), toman (Channa micropelles), dan bujuk (Channa cyanospilos). Berdasarkan pada Gambar 4 dan 5 di atas, gabus (channa striata) merupakan hasil tangkapan yang dominan yaitu 63,0 dan $48,0 \%$. Hal

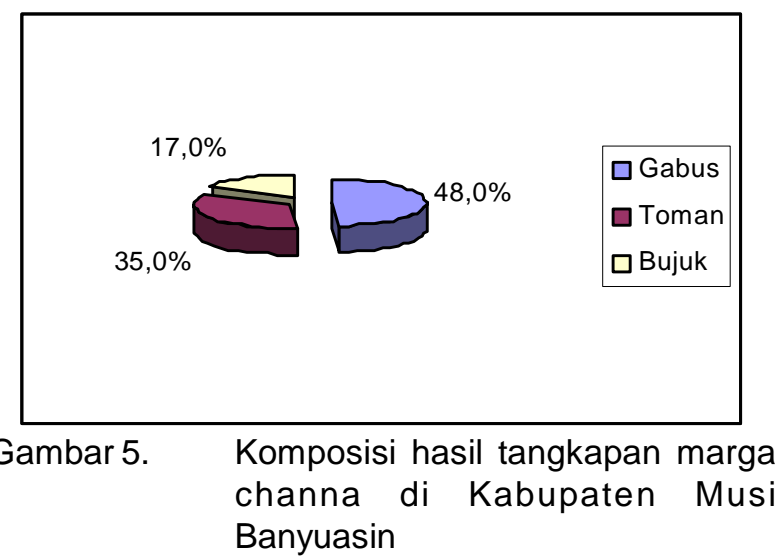

sebagai tangkai yang ditanamkan pada dasar perairan supaya tidak hanyut dan diberi umpan. Alat ini hanya digunakan di tepi sungai. Penangkapan ngesek di lebung (active barrier) yaitu menggunakan empang bambu yang digeser dan ditarik secara perlahan-lahan dengan teratur sehingga ikan terkurung pada tempat tertentu, kemudian ikan dapat diambil menggunakan alat tangkap seperti serok dan lain-lain.

\section{KESIMPULAN}

Di daerah aliran Sungai Musi ditemukan 5 jenis marga channa yaitu serandang (Channa pleurophthalmus), bujuk (Channa cyanospilos), toman (Channa micropeltes), gabus (Channa striata), dan sarko (Channa lucius). Sedangkan jenis jalai (Channa maruiloides) sudah tidak ditemukan lagi pada lokasi penelitian, hal ini kemugkinan disebabkan oleh rusaknya habitat dan penangkapan lebih.

\section{Persantunan: \\ Review-review dari hasil penelitian penulis}

\section{DAFTAR PUSTAKA}

Anonim. 2006. Channa melanopterus, Kapuas River Basin of Kalimantan Westren Borneo. 
Anonim. 2006a. Channa melanopterus, Kapuas River Basin of Kalimantan Westren Borneo.

Anonim. 2006b. Channa micropeltes. http:// fisc.er.usgs.gov/. Diakses tanggal 5 Mei 2006.

Anonim. 2006c. Channa cyanospilos. http:// fisc.er.usgs.gov/. Diakses tanggal 5 Mei 2006.

Anonim. 2006d. Channa pleurothalma. http:// fisc.er.usgs.gov/. Diakses tanggal 5 Mei 2006.

Anonim. 2006e. Tiga juta ha daerah aliran Sungai Musi Kritis.www.kompas.com. Edisi 24 Januari.

Kottelat M, Anthony J. W., Sri N. K., \& Soetikno W. 1993. Freshwater fishes of western Indonesia and Sulawesi (ikan air tawar Indonesia bagian barat dan Sulawesi). Java Books. Jakarta. P 229.

Said A., A. K. Gaffar, E. Dharyati, \& D. Muthmainah. 2004. Riset biologi ikan marga channa (gabusgabusan) di perairan umum daerah aliran Sungai
Musi, Sumatera Selatan Palembang. Laporan Teknis Balai Riset Perikanan Perairan Umum. Palembang

Samuel, S. Adjie, \& Subagja. 2002. Inventarisasi dan distribusi biota serta karakteristik habitat Sungai Musi. Laporan Teknis Balai Riset Perikanan Perairan Umum. Palembang. 32 hal.

Sriwijaya Pos. 2003. Banyak jenis ikan sungai punah. Edisi 17 September.

Utomo, A. D., Z. A. Nasution, \& S. Adjie. 1995. Pemanfaatan berbagai tipe ekosistem daerah aliran sungai melalui penerapan teknologi budi daya ikan tepat guna. Kumpulan Makalah Seminar Penyusunan, Pengolahan, dan Evaluasi Hasil Penelitian Perikanan di Perairan Umum, Palembang 27-28 Pebruari 1994. Sub Balai Penelitian Perikanan Air Tawar Palembang. Pusat Penelitian dan Pengembangan Perikanan. Badan Penelitian pengembangan Pertanian. 227-233. 